\title{
THE ROLE OF FISCAL SUSTAINABILITY IN ENHANCING SUSTAINABLE ECONOMIC GROWTH IN SOUTH ASIA: THE CASE OF BANGLADESH
}

\author{
Tapan Kumar Sarker*
}

The present paper examines the role of fiscal sustainability in achieving sustainable economic growth in the context of South Asia. Excessive government debts have long-term implications and can cause serious intergenerational consequences. In this paper, the role of fiscal sustainability is discussed and the concept of a "just tax system" is analysed. Such a tax system can play an important role in achieving economic growth that is sustainable, rather than being focused on short-term gain. Using the case of Bangladesh, the paper highlights some of the key imminent challenges to transforming a tax system to be more equitable and fair. It finds that current taxation systems are based on short-term frameworks and can leave future generations with the ultimate burden of dealing with the limitations of those systems. Based on the case study, which supports those facts, policymakers in South Asian countries could integrate longterm measures to ensure fiscal sustainability in achieving sustainable economic development.

JEL classification: H21, F62.

Keywords: Fiscal sustainability, intergenerational equity, South Asian development.

Treat the Earth well: it was not given to you by your parents; it was loaned to you by your children. We do not inherit the Earth from our ancestors, we borrow it from our children. It refers to a loan contract, the next generation being the lender and the current one the borrower. This is not the only existing proposal.

(Gosseries, 2008, p.15)

\footnotetext{
* $\quad \operatorname{PhD}$ (Australian National University), Department of International Business \& Asian Studies, Griffith Asia Institute, Griffith University, QLD 4111, Australia (Tel: 6173735 3835; fax: 617373 5111; e-mail: tapan.sarker@griffith.edu.au). Dr. Sarker is a former World Bank Scholar and a former official with the National Board of Revenue in Bangladesh. The author would like to thank Ms. Nahida Faridy for her research assistance and the anonymous reviewers of the Journal for their constructive and helpful comments on earlier versions of this paper.
} 


\section{INTRODUCTION}

This present paper examines the role of fiscal sustainability in achieving sustainable economic growth in the context of South Asia. This topic is particularly important in the light of the recent austerity measures taken in Greece and Italy, which resulted in serious social and political turmoil, including the resignation of both countries' presidents (Cabannes, 2011). There is also growing recognition that the current global patterns of consumption and investment are unsustainable, meaning that many countries must rebalance their economies towards repairing, maintaining and perhaps gaining fiscal sustainability (Sarker, 2013). This is particularly true for many developed economies, such as Japan and the Republic of Korea, which are experiencing the additional pressures of rapidly ageing populations and sluggish economic growth (Ernst and Young Global, 2011). According to analysts and scholars, reducing budget deficits by promoting fiscal discipline is one important action. For resource-rich economies, restoring fiscal sustainability entails using natural resource endowments to advance social, economic and environmental development outcomes by further broadening the tax base and aggressively enforcing existing taxes (Blanchard and Milesi-Ferretti, 2009; Ernst and Young Global, 2011; Sarker, 2011a; Scholl and others, 2010). This is important not only for current generations, but also for future generations, as the financial situation of one generation affects the next. It means that the debt reduction policies of current governments will have an impact on the level of intergenerational equity of the future generations, particularly as it relates to their living standards and the distribution of public resources (Australian, Department of Treasury, 2002). National debt can be viewed as an obligation passed from current generations to future generations. According to Auerbach (2008, p. 2):

There are at least three important long-term objectives that appear to be associated with concerns about debt and deficits: intergenerational equity; economic performance; and fiscal sustainability. Unacceptably high levels of debt are seen as compromising all three objectives.

This paper aims to contribute to the existing literature by exploring the role of fiscal sustainability in achieving intergenerational equity. In particular, it investigates the role of a "just tax system" as a tool for achieving sustainable economic growth. For this paper, the term "just" is meant to address intergenerational equity rather than intrageneratioanal equity. Hence, the scope of the paper is limited to address intergenerational equity only.

The remainder of the paper is organized as follows. Section II outlines the conceptual framework underpinning the theory of optimal taxation and discusses the importance of effective fiscal reforms and policy instruments for enhancing fiscal sustainability. Section III proposes the notion of a "just tax system" that is focused 
on achieving economic growth and is sustainable in the long run, rather than being focused on short-term gains. Section IV provides an overview of some of the key fiscal policy challenges faced by the South Asian economies in the post-global financial crisis environment. Section $\mathrm{V}$ highlights some of the key imminent challenges for the tax system in the context of Bangladesh. The final section concludes the paper and provides suggestions for future research.

\section{CONCEPTUAL REVIEW OF FISCAL SUSTAINABILITY}

Fiscal sustainability is a term that is commonly used in relation to the affordability of government taxation and spending programmes and refer to whether the Government is able to maintain current policies without major adjustments in the future (Buckle and Cruickshank, 2013). Alternatively, it can be defined as the state wherein the government budget can be smoothly financed without generating significant increases in the public debt (or money supply) over time (Adams, Ferrarini and Park, 2010). Fiscal sustainability could be static (when the budget can be financed smoothly over time) or dynamic (when the budget does not lead to significant increases in public debt). Both static and dynamic fiscal stability are important, and threats to either or both can have implications for the macroeconomic and financial stability of a country.

The long-term implications of excessive levels of government debt and government spending have important intergenerational consequences; however, they generally receive little attention from policymakers, who generally focus on short-term political gains (Sarker, 2013). The current fiscal unsustainability means that future generations of taxpayers will face an unmanageable burden for something they do not benefit from due to the consumption of the current generation (Coombs and Dollery, 2002). Furthermore, fiscal unsustainability means that the enduring well-being and quality of life of future generations has been compromised by current generations (Sarker, 2013). This is particularly important in the context of the ageing population, as many governments are faced with the reality of being unable to provide an old-age pension for the growing numbers of retirees in their countries (Thompson, 2003). Hence, achieving fiscal sustainability is an important component to enhancing intergenerational equity to prevent future generations from bearing the burden of debt incurred by current generations. Coombs and Dollery (2002, p. 12) argue that:

Governments can achieve fiscal sustainability simply by raising taxes ... it is conceivable that a government can address its own financial affairs at the expense of its citizen's welfare. Accordingly, in order to ensure that fiscal sustainability is achieved without damage to the welfare of the economy, the concept of optimal taxation should be considered. 
The theory of optimal taxation is governed by the Principles of Taxation, which were developed by Adam Smith in 1776 (Smith, 1776). These Principles state that a good tax should be proportional or equitable, certain, simple, transparent, and efficient. When considering the question of intergenerational taxation, the equity principle would at first glance seem to be the most applicable. Equity in taxation is usually assessed by asking who bears the burden of the tax, defined as the change in the distribution of private real income produced by any given tax (Kotlikoff and Summers, 1987; Sarker, 2006). A tax burden that falls most heavily on the poor is said to be "regressive", while a tax burden that falls most heavily on the rich is said to be "progressive". Progressive taxation may often be considered the most socially desirable outcome, as redistributive taxation can subsidize people with low incomes and provide a minimum level of consumption for all (Mirrlees, 2011). Public economics theory argues that an efficient form of taxation is one in which most taxes are collected by direct taxes (those on incomes, profits and capital gains). It also argues that commodity taxes, especially non-uniform commodity taxes, are distortionary, as they affect the incentives to produce a given basket of goods. Furthermore, as everyone, the poor as well as the rich, pays the same rate of tax, commodity taxes are also regressive (Jha, 2010). A remedy for this problem would be to introduce a valueadded tax (VAT). This type of tax has been an important part of tax reform in many counties. One key advantage of VAT is that as the tax base excludes inputs, there is no cascading effect. The role of VAT as a means to enhance fiscal sustainability is discussed in section $\mathrm{V}$ in this paper using the case of Bangladesh.

There is also a well-acknowledged trade-off between equity and efficiency. Policymakers must negotiate this because a steeply progressive tax system can remove incentives to work (Pressman, 2002). As a result, policymakers often assess whether a taxpayer ought to be bearing that particular tax burden based on two principles: the benefit principle and the ability to pay principle. The benefit principle states that people should pay tax according to the benefits they receive from government spending of that tax revenue. This would seem to imply that the present generation, who is receiving the benefits of the mining boom, should pay taxes according to those benefits received (Auerbach, 1983). By contrast, the ability to pay principle states that those who are more capable of bearing the burden of taxation should pay more taxes than those with less ability to pay. Hence, effective fiscal reform and policy instruments can enhance, maintain or repair fiscal sustainability, thus playing a role in helping a country achieve sustainable economic development.

However, equity considerations under the Principles of Taxation are focused on determining the short-term redistributive impact of a proposed change in taxation. A number of different types of equity could also be considered, such as intertemporal equity (impact on long-term decisions); intergenerational equity (future generations); 
and spatial equity (urban-rural divide) (Australia, 2010). As policymakers are increasingly being required to grapple with designing a tax policy to meet long-term challenges, such as intergenerational debt concerns or the ageing population, there is beginning to be a shift away from the traditional concept of equity in taxation to a much broader notion of "justice" in taxation that takes long-term intergenerational considerations into account (Sarker, 2013).

\section{A "JUST TAX SYSTEM"}

While assessments of equity in taxation review short-term considerations, the notion of a "just tax system" adopts a longer-term, intergenerational perspective. According to Thompson (2003), three different conceptions of societal justice are commonly used. These are the mutual advantage theory, the entitlement theory and justice as fairness. The mutual advantage notion of justice is essentially a costbenefit analysis, and is satisfied when each person derives the maximum possible gains from voluntary cooperation. The entitlement theory notion of justice focuses on rewards and punishments, and is satisfied when all members of society get what they deserve. The notion of justice as fairness is the most relevant to a tax system; it focuses on the intergenerational distribution of wealth, or intergenerational equity (Sarker, 2013). Justice as fairness holds that all individuals should be able to enjoy a fair share of resources regardless of their history, opportunities, or origin (Thompson, 2003). Under the principle of justice as fairness, current and future generations should have the same access to resources, wealth and consumption opportunities, and intergenerational rebalancing may be required where this does not currently occur (Ablett, 1996).

To move beyond a merely theoretical notion of intergenerational rebalancing, it is necessary to be able to quantify the extent of generational imbalance to determine the adjustment required to rebalance the generations. Generational accounting is one tool that used to determine the amount of intergenerational rebalancing necessary to achieve "justice" in enhancing intergenerational equity. It is based on the premise that future generations should not pay a higher share of their lifetime incomes to the government than current generations do (Auerbach, Gokhale and Kotlikoff, 1994). Generational accounting states the government's intertemporal budget constraint as the present value of remaining net tax payments of existing generations plus the present value of net tax payments of future generations, which is equal to the present value of all future government consumption less government net wealth. Generational balance is then assessed by comparing the per capita fiscal burdens of current and future generations (Sarker, 2013). If the net fiscal burden of the future generation is significantly higher than the current generation, the assumed policy scenario is unsustainable (Ablett, 1996; Auerbach, Gokhale and Kotlikoff, 1994; Coombs and 
Dollery, 2002). The generational accounting framework described above posits that an increase in the consumption of current generations without an increase in the tax currently paid will result in an increased fiscal burden to be borne by future generations (Auerbach, Gokhale and Kotlikoff, 1994; Deutsche Bundesbank, 2001). Generational accounting can thus be used as a tool to design policies aimed at achieving intergenerational equity.

The sovereign wealth fund of Norway is a leading result of a policy designed to achieve intergenerational equity. According to the United Nations Human Development Index, Norway has the highest living standards in the world (UNDP, 2013). The country owes its prosperity to exporting its rich oil and gas deposits. Usually, resource-rich countries typically spend their resource wealth, which means current generations often experience higher standards of living than future generations (Corden and Neary, 1982). By contrast, Norway has adopted a different approach. The sovereign wealth fund was established to retain and invest surpluses from taxing the country's oil and gas sales at a high rate (Sunley, Baunsgaard and Simard, 2003). It aims to maintain the living standards and pension payments of future generations when its natural resource deposits are depleted. The fund, which is the second largest sovereign wealth fund in the world, is an excellent example of how policymakers can secure intergenerational equity by taxing current generations to provide for future generations (Kunzel and others, 2011; Reiche, 2010; Norwegian Ministry of Finance, 2007), while also facilitating the transition from one form of capital to another.

The Five Capital Model is another example used to provide a framework for examining trade-offs between the different but interconnected forms of capital, which are: natural capital; human capital; social capital; manufactured capital; and financial capital (Brereton and Pattenden, 2007; Porritt, 2003; Sigma Project, 2003). The Five Capital Model framework implies that those forms of capital should be repaired, maintained and enhanced rather than depleted or degraded (Mikesell, 1989). As taxation policy can affect business incentives, it can be used to facilitate intergenerational redistribution by assisting the transition from one form of capital to another. Rather than depleting one form of capital altogether (Mikesell, 1989), the focus should be on achieving optimal outcomes across all forms of capital (Southalan, 2011). The model implies that the income generated from natural resource extraction, such as depletion of natural capital, should not be entirely used for consumption. Instead, the revenue from natural resources should be retained and used to develop another form of capital, such as human capital, financial capital, manufactured capital or social capital. The sovereign wealth fund of Norway is an example of this; a portion of the country's revenues from oil and gas extraction (the depletion of natural capital) are retained and used for pension payments for a future ageing population (enhancing human capital). This also applies to resource rich developing countries, which often 
face the prospect of a natural resource curse by not being able to accumulate mineral wealth for investment (Kazi and Sarker, 2012). Collier (2010, p. 78) argues that:

In resource rich low income countries ... the key fiscal issue to be addressed is the replacement of depleting natural assets with other assets, real and financial ... the revenues need to be earmarked for investment.

Figure 1 graphically shows how the components of a just tax system can be derived from the above discussion. A just tax system can help achieve fiscal sustainability and intergenerational equity by maintaining and developing capital, rather than depleting it. Simultaneously, it focuses on achieving economic growth that is sustainable, rather than being focused on short-term gains.

Figure 1. A "just" tax system

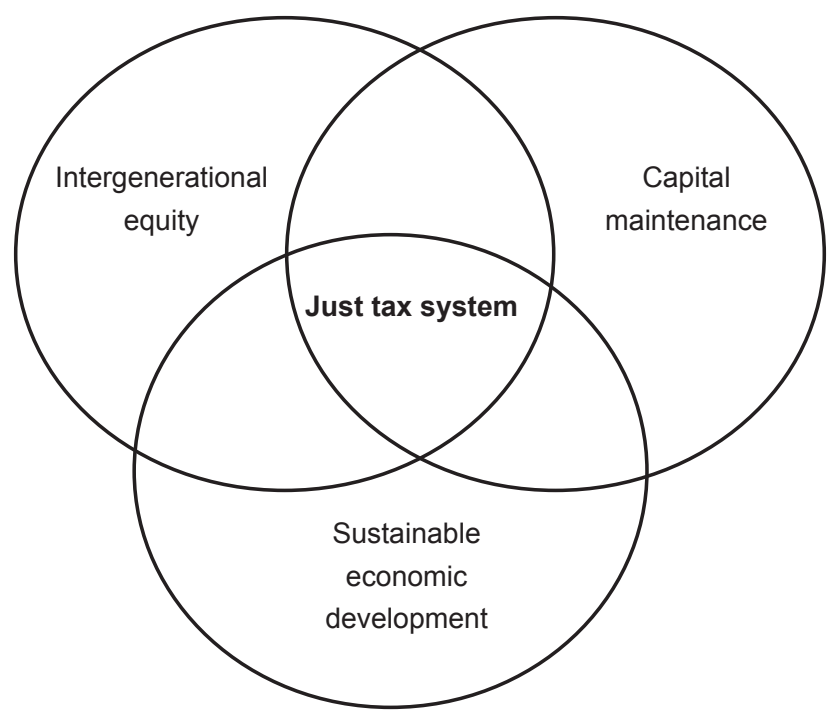

Source: Sarker (2013).

The leftmost circle refers to the relationship between intergenerational equity and fiscal sustainability. As national debt can be inherited by future generations, fiscal sustainability is necessary to reduce excessive national debt and achieve intergenerational balance. The circle on the right describes how the Five Capital Model advocates for capital maintenance rather than depletion. Fiscal sustainability in the long term often requires investing in the five forms of capital and ensuring that such capital is maintained for future generations. This capital investment may be in a number of different forms, including education and human capital development or establishing 
a sovereign wealth fund. The final circle, sustainable economic development, refers to economic growth that is sustainable, taking into account social and environmental welfare. Fiscal sustainability and intergenerational equity are necessary to achieve government spending and economic growth that is sustainable. Capital maintenance also contributes to achieving economic growth that is sustainable, as extensive capital depletion will eventually hinder economic growth. As shown in figure 1, these long-term policy objectives are interrelated, and that the nexus of the three of them can be used to describe a "just" tax system that simultaneously achieves all three objectives.

\section{STRENGTHENING FISCAL SUSTAINABILITY IN THE SOUTH ASIAN SUBREGION}

Policymakers around the world are trying to find ways towards achieving fiscal sustainability through effective fiscal policy reforms. Examples of such policies include municipal amalgamation to strengthen the financial viability of local government in Canada (Slack and Bird, 2013) or phasing out corporate tax breaks in China (Shuhong, Zhenzi and van der Hoek, 2008). Strengthening fiscal sustainability has both shortand long-term implications for the countries in the South Asian subregion. In the short term, high government debt can increase the cost of borrowing. This may, in turn, restrict some of the potentially productive private sector economic activity. A higher level of government debt also means that the government faces higher interest costs each year, at the expense of other government spending. In the long term, high debt burdens may cause problems for future generations in the form of higher tax rates than would otherwise be the case, as debt eventually needs to be repaid (New Zealand Treasury, 2013). While the issue is most pressing in debt-stricken developed countries and regions, such as the United States of America, Japan and Europe, developing countries in the South Asian region are also trying to make drastic policy changes to address long-term social and economic challenges by redesigning their taxation systems.

Gross domestic product (GDP) in South Asia has slowed recently. It only grew an estimated 4.7 per cent in market price terms in 2013, as compared with 5.0 per cent in the previous year (World Bank, 2014b). Fiscal deficits in the region are relatively high, and government debt ratios are also high in some countries (Bhutan, India, and Pakistan), which reflects weak revenue mobilization, a factor behind fiscal imbalances in the South Asian countries as shown in table 1. As a potential drag on economic growth, fiscal consolidation measures in the subregion is crucial and should be considered as a necessary step towards restoring fiscal sustainability (World Bank, 2015). However, successful fiscal consolidation requires long-term fiscal reforms to 
improve the existing low tax to GDP ratios. This is particularly important to ensure fiscal sustainability and increase the resources required in meeting the Millennium Development Goals and poverty reducing expenditures. Another threat to South Asian countries is the impact of climate change. According to a recent report by the Asian Development Bank (2014), climate change is likely to slash up to nine per cent off the South Asian economy every year by the end of the century. The human and financial toll could be even higher if the damage from floods, droughts, and other extreme weather events is included. The report also suggests that if the world continues on its current path, South Asia will need to spend at least $\$ 73$ billion, or an average of 0.86 per cent of its GDP, every year between now and 2100 to adapt to climate change. Such impacts would pose added pressure to enhance and rebuild fiscal sustainability in the South Asian economies.

Table 1. South Asia forecast summary

\begin{tabular}{lcccccc}
\hline & $\mathbf{2 0 1 0}$ & $\mathbf{2 0 1 1}$ & $\mathbf{2 0 1 2}$ & $\mathbf{2 0 1 3}$ & $\mathbf{2 0 1 4}$ & $\mathbf{2 0 1 5}$ \\
\hline GDP at market prices & 9.7 & 7.3 & 5.0 & 4.7 & 5.3 & 5.9 \\
Fiscal balance/GDP (\%) & -7.8 & -7.5 & -7.2 & -6.9 & -6.7 & -6.6 \\
Current account balance/ GDP (\%) & -2.7 & -3.1 & -4.1 & -2.2 & -2.0 & -2.2 \\
\hline
\end{tabular}

Source: World Bank (2014b).

Developing countries, in general, face benign cyclical environments to build fiscal buffers and to restore fiscal sustainability. This, however, is not the case in South Asia as the countries in this subregion have been confronted with a sudden decline in international capital flows in the recent years. For instance, while real GDP growth in India has increased steadily, other countries in the subregion, such as Bangladesh and Pakistan, may not see similar growth, partly due to low political stability, and poor governance, which pose a serious threat to their economic growth (World Bank, 2014b). Furthermore, countries in the South Asian region often provide generous energy subsidies that distort activity and are seen as impediments to private sector activity. Notably, however, the recent dramatic fall in oil prices could provide an opportunity to rebuild fiscal space while removing the economic distortions associated with subsidies in the subregion.

In general, countries in the South Asia region have shown varied levels of economic growth since the fiscal year $2009 / 10$ as shown in table 2. However, these countries need to rebuild fiscal policy space, as many of them used their buffers as a consequence of the great financial crisis. This means that the successfully consolidating the budget in the near term and achieving sustainability will rely on 
revenue mobilization mainly through effective tax policy reforms. Some of the key policy implications that could strengthen fiscal sustainability in selected South Asian economies, namely Bangladesh, India, Pakistan, Sri Lanka, and Nepal, are discussed below.

Table 2. South Asia: selected economic indicators (as \% of GDP)

\begin{tabular}{|c|c|c|c|c|c|c|c|}
\hline & Country & $2009 / 10$ & $2010 / 11$ & $2011 / 12$ & $2012 / 13$ & $2013 / 14$ & $\begin{array}{l}2014 / 15 \\
\text { (projected) }\end{array}$ \\
\hline \multirow[t]{5}{*}{ GDP growth } & Bangladesh & 5.7 & 6.1 & 6.7 & 6.2 & 6.0 & 5.5 \\
\hline & India* & 8.6 & 9.3 & 6.2 & 5.0 & 4.6 & 5.4 \\
\hline & Pakistan & 2.6 & 3.7 & 4.4 & 3.6 & 3.3 & 3.1 \\
\hline & Nepal & - & 3.4 & 4.8 & 3.9 & 4.8 & 5.0 \\
\hline & Sri Lanka & 3.5 & 8.0 & 8.2 & 6.4 & 6.3 & 6.8 \\
\hline \multirow{5}{*}{$\begin{array}{l}\text { Revenue and } \\
\text { grants }\end{array}$} & Bangladesh & & & 11.9 & 12.9 & 12.9 & 13.2 \\
\hline & India* & 9.2 & 9.0 & 8.7 & 9.1 & 9.1 & 9.3 \\
\hline & Pakistan & 14.3 & 12.6 & 13.1 & 13.2 & 13.0 & 12.8 \\
\hline & Nepal & - & 17.7 & 18.7 & 19.3 & 21.1 & 21.3 \\
\hline & Sri Lanka & 15.0 & 14.9 & 14.5 & 13.2 & 13.4 & 13.9 \\
\hline \multirow[t]{5}{*}{ Revenue } & Bangladesh & & & 11.7 & 12.4 & 12.4 & 12.6 \\
\hline & India* & 9.2 & 9.0 & 8.7 & 9.1 & 9.1 & 9.3 \\
\hline & Pakistan & 14.0 & 12.4 & 12.8 & 13.0 & 13.9 & 14.1 \\
\hline & Nepal & - & 14.4 & 16.0 & 17.7 & 18.4 & 18.3 \\
\hline & Sri Lanka & 14.5 & 14.6 & 14.3 & 13.0 & 13.2 & 13.7 \\
\hline \multirow[t]{5}{*}{ Tax revenue } & Bangladesh & 8.6 & 9.0 & 10.0 & 10.4 & 10.4 & 10.5 \\
\hline & India* & 7.1 & 7.4 & 7.1 & 7.4 & 7.3 & 7.5 \\
\hline & Pakistan & 10.1 & 9.5 & 10.3 & 9.7 & 9.8 & 9.8 \\
\hline & Nepal & - & 12.6 & 13.5 & 15.3 & 16.3 & 16.7 \\
\hline & Sri Lanka & 12.8 & 12.9 & 12.4 & 11.1 & 11.7 & 12.1 \\
\hline \multirow[t]{5}{*}{ Expenditure } & Bangladesh & & & 16.0 & 16.3 & 16.9 & 16.9 \\
\hline & India* & 16.1 & 15.4 & 14.8 & 14.2 & 14.3 & 14.9 \\
\hline & Pakistan & 20.2 & 19.5 & 21.5 & 21.7 & 20.8 & 20.8 \\
\hline & Nepal & - & 18.7 & 19.3 & 17.9 & 20.8 & 21.1 \\
\hline & Sri Lanka & 24.9 & 22.8 & 21.4 & 19.7 & 19.3 & 19.3 \\
\hline
\end{tabular}


Table 2. (continued)

\begin{tabular}{llcccccc}
\hline & \multicolumn{1}{c}{ Country } & $\mathbf{2 0 0 9 / 1 0}$ & $\mathbf{2 0 1 0 / 1 1}$ & $\mathbf{2 0 1 1 / 1 2}$ & $\mathbf{2 0 1 2 / 1 3}$ & $\mathbf{2 0 1 3 / 1 4}$ & $\begin{array}{c}\mathbf{2 0 1 4 / 1 5} \\
\text { (projected) }\end{array}$ \\
\hline $\begin{array}{l}\text { Overall fiscal } \\
\text { balance }\end{array}$ & Bangladesh & & & -4.1 & -4.0 & -4.5 & -4.3 \\
& India* & -7.0 & -6.4 & -6.0 & -5.1 & -5.3 & -5.6 \\
& Pakistan & -5.9 & -6.9 & -8.4 & -8.5 & -7.8 & -8.0 \\
& Nepal** & - & -2.6 & -2.7 & -2.0 & -2.2 & -1.5 \\
& Sri Lanka & -9.9 & -8.0 & -6.9 & -6.4 & -5.8 & -5.4 \\
\hline Total public & Bangladesh & & & 65.4 & 67.2 & 57.6 & 55.9 \\
& India* & 72.5 & 67.4 & 67.0 & 67.6 & 67.3 & 67.3 \\
& Pakistan & 61.5 & 59.5 & 63.8 & 66.6 & 69.2 & 71.9 \\
& Nepal & - & 34.5 & 36.3 & 31.5 & 30.2 & 30.5 \\
& Sri Lanka & 86.1 & 81.9 & 78.4 & 80.2 & 79.9 & 78.0 \\
\hline
\end{tabular}

Sources: IMF Country Reports (2013-2014) and authors own compilation. Note: ${ }^{*}$ India (Central Government's data), ${ }^{* \star}$ Nepal (excluding grants).

The economy of Bangladesh has maintained a level of performance consistent with previous years; although rising inflation, high underemployment, and budget and trade deficits continue to be concerns. Economic performance has continued to be strong in the fiscal years 2011 and 2012, with GDP growth ${ }^{\circ}$ of 6.1 per cent and 6.7 per cent, respectively. Concerns about the possible effects of global climate change have led to robust public discourse, insightful research projects and policy interventions in recent years. The government and the civil society are engaged not only in raising awareness but also in devising policies to mitigate projected effects (BTI, 2014). According to IMF (2013a), strengthened revenue administration and reforms in VAT and income tax legislation have helped boost tax collection in the country.

Among the South Asian countries, the financial system of India is well capitalized and supervised, but, according to IMF (2014a), the country still needs to undergo fiscal consolidation and there is scope to improve the quality of fiscal adjustment. In addition, containing persistently high inflation and a firm commitment to reducing the debt generating fiscal deficits are critical for achieving higher long-term growth.

The tax to GDP ratio for 2012/13 was 9.7 per cent, which is significantly less than the 11.4 per cent ratio in 2002/03 (IMF, 2013b). This means that fiscal consolidation will have to rely heavily on tax policy changes to broadening the tax base. The implementation of a full value-added tax remains the first-best option to raise tax revenue (Hassan and Sarker, 2012), but if this remains politically unfeasible, other 
permanent tax policy measures could be considered, such as wholesale reductions in exemptions and concessions, and by fully incorporating services into the tax net.

In Sri Lanka, tax revenues have been declining as a per cent of GDP for years, and are now considered low by international standards (IMF, 2013c). In 2011, the first round of reforms involving rationalizing taxes, rate reductions and some base broadening were implemented. Notwithstanding, the tax revenue-to-GDP ratio was estimated to have fallen to level that slightly exceeds 11 per cent in 2012, lower than most other countries in the subregion. Similar to other South Asian economies, a critical issue in Sri Lanka is the need to strengthen the revenue system to support consolidation while making space for capital investment and key social spending in order to sustain robust and inclusive growth. The second generation of tax reform focused on base broadening and improving administration. Notably, addressing losses at state-owned energy companies requires a comprehensive approach.

In Nepal, revenue growth has remained strong, owing to high import growth and ongoing administrative reforms in the inland revenue and customs departments (IMF, 2014b). According to IMF (2014b), the country's fiscal policy needs to support growth through higher public investment. Key areas with a large impact on potential growth are power generation and distribution, and transport. Investments in those areas would also likely crowd in private sector investment, as they would provide the essential infrastructure for agriculture and industry. Spending on health and education has increased significantly in recent years, including through donor support.

\section{A CASE STUDY OF BANGLADESH}

Bangladesh is a developing country located in South Asia, with an estimated 32 per cent of the population living below the poverty line (World Bank, 2014a). Growth in Bangladesh averaged 6.3 per cent during the period 2010-2013, but slowed to an estimated 5.4 per cent during the fiscal year ending in June 2014. Social unrest and low political stability, among other things, have impeded efforts in recent years to improve fiscal sustainability. The fiscal cost of food and fuel subsidies in Bangladesh is also heavy, and its energy subsidy alone amounts to between 6 to 10 per cent of revenues (IMF, 2013a). The country faces low tax/GDP ratios and inelastic expenditure/ GDP ratios, which often lead to structurally entrenched fiscal deficits. According to IMF (2013a), the relatively low tax/GDP ratio of Bangladeshis is primarily due to inherent weakness in the taxation system. Table 3 provides an illustration of the tax revenue as a percentage of GDP in Bangladesh. 
Table 3: Evolution in tax revenue in Bangladesh (in \% of GDP)

\begin{tabular}{lcrrrrc}
\hline & $\mathbf{2 0 0 9 / 1 0}$ & $\mathbf{2 0 1 0 / 1 1}$ & $\mathbf{2 0 1 1 / 1 2}$ & $\mathbf{2 0 1 2 / 1 3}$ & $\mathbf{2 0 1 3 / 1 4}$ & $\begin{array}{c}\mathbf{2 0 1 4 / 1 5} \\
\text { (projected) }\end{array}$ \\
\hline Total revenue & 10.9 & 11.7 & 12.4 & 13.2 & 13.6 & 14.2 \\
Tax revenue & 9.0 & 10.0 & 10.4 & 10.9 & 11.3 & 12.2 \\
NBR tax collection & 8.6 & 9.6 & 10.0 & 10.5 & 10.9 & 11.8 \\
VAT and supplementary duties & 4.9 & 5.4 & 5.5 & 5.5 & 5.6 & 6.4 \\
Customs and excise duties & 1.4 & 1.4 & 1.4 & 1.5 & 1.4 & 1.5 \\
Taxes on income and profit & 2.3 & 2.8 & 3.1 & 3.5 & 3.7 & 3.9 \\
\hline
\end{tabular}

Sources: Bangladesh, National Board of Revenue (NBR) (2014); and authors/own compilation.

As shown in the above table, Bangladesh has been experiencing low tax/GDP ratios, which has only slightly improved in recent years. The poor performance in revenue mobilization reflects weakness embedded in the tax policy and in revenue administration, which indicates that limited effort has gone into revenue collection. This low tax effort is largely explained by the significant amount of tax revenue foregone due to preferential tax treatment given to specific taxpayer groups or to investment expenditures or their returns through targeted tax deductions, credits, tax exclusions or exemptions (IMF, 2011b). An assessment by the Bangladesh National Board of Revenue in 2007 estimated that foregone revenue could be as much as 2.5 per cent of GDP (Bangladesh, National Board of Revenue, 2007).

Revenue collections of Bangladesh as a percentage of tax revenue are shown by tax category in table 4. It shows that VAT stands as the largest source of revenue collection in Bangladesh; however, the share is limited and has ranged between 32 per cent and 39 per cent since fiscal year 2000/01. In addition, the data presented in the following table also show a gradual growth in income tax collection and a decline in international trade tax, such as customs duty and supplementary duty.

The table also indicates the country's heavy reliance on indirect tax, more specifically on VAT. The argument that personal income tax, generally considered to be the most effective means of taxing the rich, is relatively unimportant in most developing countries (Bird and Gendron, 2005), holds convincingly true for Bangladesh. The predominance of indirect taxes in revenue yield over direct taxes is evident as direct taxes accounted for only 35 per cent of the tax revenue in 2013/14 while indirect taxes accounted for about 65 per cent. The number of people within the personal income tax net equally indicates the malnourished tax culture of the country. For instance, only 1.17 per cent of the Bangladesh population is registered for personal income tax and of those, less than 1 per cent actually pays any income tax. VAT is one of the largest taxes in the country. It accounts for a substantial share of its tax 
revenue even though only 13 per cent of the businesses are registered under VAT (Bangladesh, National Board of Revenue, 2014).

Table 4. Contribution of the different taxes as percentage of total tax revenue

\begin{tabular}{cccccccc}
\hline Years & $\begin{array}{c}\text { Income } \\
\text { tax }\end{array}$ & VAT & $\begin{array}{c}\text { Customs } \\
\text { duty }\end{array}$ & SD & $\begin{array}{c}\text { Excise } \\
\text { duty }\end{array}$ & $\begin{array}{c}\text { Other } \\
\text { taxes }\end{array}$ & Total (\%) \\
\hline $2000 / 01$ & 18.70 & 33.90 & 26.94 & 18.12 & 1.47 & 0.87 & 100 \\
$2001 / 02$ & 19.80 & 33.33 & 25.60 & 18.57 & 1.40 & 1.30 & 100 \\
$2002 / 03$ & 20.21 & 33.61 & 24.47 & 18.48 & 1.30 & 1.93 & 100 \\
$2003 / 04$ & 19.51 & 31.70 & 26.98 & 20.07 & 0.62 & 1.12 & 100 \\
$2004 / 05$ & 19.18 & 34.77 & 26.22 & 18.36 & 0.49 & 1.37 & 100 \\
$2005 / 06$ & 20.23 & 35.48 & 23.90 & 18.55 & 0.47 & 1.37 & 100 \\
$2006 / 07$ & 23.86 & 36.50 & 22.08 & 16.26 & 0.49 & 0.81 & 100 \\
$2007 / 08$ & 23.47 & 37.00 & 20.23 & 17.33 & 0.46 & 1.51 & 100 \\
$2008 / 09$ & 25.54 & 37.95 & 18.02 & 17.20 & 0.55 & 0.74 & 100 \\
$2009 / 10$ & 27.59 & 38.84 & 15.13 & 17.22 & 0.56 & 0.66 & 100 \\
$2010 / 11$ & 28.89 & 37.78 & 14.44 & 17.08 & 0.61 & 0.52 & 100 \\
$2011 / 12$ & 29.92 & 37.54 & 14.12 & 17.72 & 0.70 & 0.53 & 100 \\
$2012 / 13$ & 31.44 & 36.13 & 12.92 & 17.78 & 0.88 & 0.85 & 100 \\
$2013 / 14$ & 35.49 & 36.75 & 10.75 & 15.32 & 0.96 & 0.73 & 100 \\
\hline
\end{tabular}

Sources: Bangladesh, Ministry of Finance (2014); and authors' own compilation.

Note: SD = Supplementary duty.

The United Nations ranked Bangladesh in the low human development category in 2012, but it also highlighted the country for having made substantial progress since their last evaluation in 2011 (UNDP, 2013). Given the extremity of the development problems experienced by Bangladesh, policies that work in the country are likely to provide guidance to other developing economies experiencing less extreme conditions. According to the Asian Development Bank (2004) and others (IMF, 2011a; Kim, 2005), effective fiscal policies directed at achieving sustainable economic development are crucial for poverty alleviation in developing countries, such as Bangladesh. However, such tax policy reform should be country specific, as taxes that work in one country may not be effective in another country context (Mirrlees, 2011; Tanzi and Zee, 2001).

Bangladesh is also highly vulnerable to the impacts of climate change, owing to its location and large proportion of low-lying land subject to inundation as sea levels rise (Sarker and Azam, 2014). The country's vulnerability to climate change poses a serious impediment to long-term economic development (Agrawala and 
others, 2003). To mitigate this vulnerability, significant internal and external funding is required (Sarker and Azam, 2014). The Bangladesh Climate Change Resilience Fund, which was established in 2010, is enabling the Government to channel more than $\$ 188$ million in grant funds to millions of Bangladeshis to build their resilience to the effects of climate change.

Apart from the climate change issue, Bangladesh also faces the mounting task of increasing funding for education and human capital development, which can help long-term economic development. The country's new education policy has addressed this issue and has notably received much attention in recent years as a key mean of improving its GDP growth and redressing inequality. It is estimated that between 42 and 51 per cent of the population is currently illiterate, and that 38 per cent of the population has received no formal education (Bangladesh Bureau of Statistics, 2010; Bangladesh, Ministry of Education, 2010). The recent National Education Policy 2010 of Bangladesh acknowledges the importance of expanding the provision of quality education in this country, which according to education policy experts would require more than 30 trillion Bangladesh taka (TK) (approximately US $\$ 37.5$ billion) (Haque, 2011). However, State-provided or subsidized education raises the question of funding, with developing countries, in particular, facing severe funding limitations (International Institute for Education Planning, 2007; World Bank, 2014a). Developing countries seeking to alleviate poverty by expanding the education sector are facing acute financing problems, and hence, must look to new sources of revenue, mainly through internal resource mobilization, which require effective fiscal policy reform (Lewin and Caillods, 2001; Wang, Zheng and Zhao, 2012).

However, finding a new tax base to fund and implement such an important policy is a daunting task for any developing country. Bangladesh is no exception, as the country has massive funding costs for its ambitious education plan. One possible option suggested was to expand the tax base on land and property, which has received renewed attention in recent years. Importantly, this would provide a degree of transparency as the property tax would be imposed on a relatively immobile base (making it difficult to evade), and would be based on land and property valuations (FAO, 2002). Education and tax experts of Bangladesh have suggested that a property tax could address the problem of education funding and raise substantial revenue, if managed properly (Haque, 2011; Sarker, 2011a). This taxation method has been used in other countries, including the United States of America, to fund local schools (Kenyon, 2007). One way this type of taxation could be implemented would be to allocate such revenue collected separately for the purpose of funding local schools. This may have a significant redistributive impact by increasing the taxation on the wealthier members of society, and contributing funds to raising the education level of many others. This is crucial in a developing nation to alleviate poverty and stimulate economic growth (Haque, 2011; Sarker, 2011b). 
Increasing a country's level of education has significant short-term and longterm benefits at both the individual and social levels. Education is a well-recognized driving factor behind increased social mobility, reduced inequality, increased living standards and poverty alleviation. According to a number of international bodies (International Finance Corporation, 2001; OECD, 2010; World Bank, 2014a), it also increases the productivity of the labour force and its health and economic growth. In addition, it drives economic competitiveness and promotes democracy, peace, stability and environmental preservation. Education is thus not only crucial to achieving short-term economic growth, but also to attaining long-term intergenerational equity objectives, such as higher living standards and lower poverty rates. A property tax in Bangladesh may assist in achieving these goals by easing inequality, as well as investing in education, thus providing a double dividend for such a poor nation.

A second tax in Bangladesh that may assist in achieving intergenerational equity is VAT (Faridy and Sarker, 2011; Sarker, 2013). Widely considered to be one of the more efficient taxes, VAT, if introduced in place of more narrowly based indirect taxes, can lead to significant efficiency gains (Ebrill and others, 2002; KPMG, 2011). Across the Asia-Pacific region, there has been a de facto broadening of the VAT tax base through targeted compliance programmes (Ernst and Young Global, 2013). Bangladesh introduced VAT in 1991, but many exemptions have hindered its revenue-raising potential (Faridy and Sarker, 2011), thus, there is a strong argument for broadening the base of VAT in Bangladesh. Effective mobilization of internal revenue is crucial for the ongoing economic development of Bangladesh, as government-provided welfare can assist in achieving poverty alleviation. Mobilization of internal revenue sources can also help to ensure the long-term fiscal sustainability of Bangladesh, as it can help reduce the country's dependence on foreign funding sources, and therefore reduce government deficits (Faridy and Sarker, 2011). Similar arguments have been made in the United Kingdom of Great Britain and Northern Ireland in the context of the economic recovery from the global financial crisis, where it was proposed that the VAT rate be increased to 20 per cent to assist the government's fiscal consolidation and debt reduction (Fuest, 2009). Obtaining enough foreign loans to finance its $\$ 395$ billion deficit has been a problem for Bangladesh in the past (Bangladesh, 2010). Essentially, broadening the VAT base would help Bangladesh achieve fiscal sustainability, which helps intergenerational rebalancing. 


\section{CONCLUSIONS}

This paper has highlighted a range of factors that policymakers should consider in designing a just tax system. The long-term social, economic and environmental sustainable development challenges faced by a country must be integrated into its tax reform agenda, along with the long-term distributional implications of its current tax system. Easing the intergenerational imbalance needs to be addressed by maintaining the various forms of capital rather than their depletion. Implementing taxes on unsustainable "bads" will incentivize a focus on more sustainable development and allow for funds to be reallocated towards increasing long-term economic productivity. Finally, consideration needs to be given to long-term issues, such as ageing populations and climate change, in present-day policy development along with efficient, simple and transparent fiscal policy development. 


\section{REFERENCES}

Ablett, J. (1996). Generational accounting and intergenerational balance. Agenda, vol. 3, No. 4, pp. 407-418.

Adams, C., B. Ferrarini, and D. Park (2010). Fiscal sustainability in developing Asia. Economics Working Paper Series, No. 205. Manila: ADB.

Agrawala, S., and others (2003). Development and climate change in Bangladesh: focus on coastal flooding and the Sundarbans. COM/ENV/EPOC/DCD/DAC(2003)3/FINAL. Paris: OECD.

Asian Development Bank (2004). Economic Growth and Poverty Reduction in Bangladesh. Manila.

(2014). Climate change threatens South Asian economy, bank warns, 20 August. Available from http://ens-newswire.com/2014/08/20/climate-change-threatens-southasian-economy-bank-warns/.

Auerbach, Alan J. (1983). The Taxation of Capital Income. Cambridge, MA: Harvard University Press. (2008). Long-term objectives for government debt. Paper presented at a conference on Fiscal Policy and Labour Market Reforms organized by the Swedish Fiscal Policy Council (Finanspolitiska RÂdet). Stockholm, 29 January.

Auerbach, Alan J., J. Gokhale, and Laurence J. Kotlikoff (1994). Generational accounting: a meaningful way to evaluate fiscal policy. The Journal of Economic Perspectives, pp. 73-94.

Australian, Department of Treasury (2002). Budget 2002-2003. Canberra.

(2010). What does equitable distribution mean? Australia's future tax system: architechture of Australia's tax and transfer system. Canberra.

Bangladesh Bureau of Statistics (2010). Report on the Bangladesh Literacy Survey. Dhaka: Ministry of Planning.

Bangladesh desperate for foreign loans to meet budget deficit (2010). Xinhua, 18 April. Available from http://english.peopledaily.com.cn/90001/90778/90858/90863/6954688.html.

Bangladesh, Ministry of Education (2010). National education policy 2010. Available from http:// planipolis.iiep.unesco.org/upload/Bangladesh/Bangladesh_National_Education_ Policy_2010.pdf.

Bangladesh, Ministry of Finance (2014). Economic Review 2014. Dhaka.

Bangladesh, National Board of Revenue (2007). Annual Report of the National Board of Revenue, 2005-2006. Dhaka.

(2014). Annual Report of the National Board of Revenue, 2011-2012. Dhaka.

Bird, R.M., and P. Gendron (2005). VAT Revisited: A New Look at the Value Added Tax in Developing and Transitional Countries. United States Agency for International Development.

Blanchard, O.J., and G.M. Milesi-Ferretti (2009). Global Imbalances: In Midstream? Washington, D.C.: IMF.

Brereton, D., and C. Pattenden (2007). Measuring what matters: monitoring the contribution of a new mining project to community sustainability. Paper presented at the $3^{\text {rd }}$ International Conference on Sustainable Development Indicators in the Minerals Industry. Milos Island, Greece. 
BTI (2014). Bangladesh Country Report. Gütersloh: Bertelsmann Stiftung.

Buckle, R., and A. Cruickshank (2013). The requirements for long-run fiscal sustainability. Working Paper, 13/20 (July). New Zealand Treasury.

Cabannes, A. (2011). The European monetary crisis explained. Available from http://papers.ssrn. com/sol3/papers.cfm?abstract_id=1911816.

Collier, P. (2010). Principles of resource taxation for low-income countries. In The Taxation of Petroleum and Minerals: Principles, Problems and Practice, Philip Daniel, Michael Keen and Charles McPherson, eds. Oxon, UK: Routledge.

Coombs, G., and B. Dollery (2002). An analysis of the debate of intergenerational equity and fiscal sustaniability in Australia. Australian Journal of Social Issues (Australian Council of Social Service), vol. 37, No. 4, p. 363.

Corden, W.M., and J.P. Neary (1982). Booming sector and de-industrialisation in a small open economy. The Economic Journal, vol. 92, No. 368, pp. 825-848.

Deutsche Bundesbank (2001). The long-term sustainability of public finance - an analysis based on generational accounting. Monthly Report of the Deutsche Bundesbank, vol. 53, No. 12, pp. 29-43.

Ebrill, L., and others (2002). The allure of the value-added tax. Finance and Development (English ed.), vol. 39, No. 2, pp. 44-47.

Ernst and Young Global (2011). Asia-Pacific tax policy outlook. Global Tax Policy. Available from http://emergingmarkets.ey.com/2011-asia-pacific-tax-policy-outlook/.

(2013). Asia-Pacific tax policy outlook. Global Tax Policy. Available from www.ey.com/ GL/en/Services/Tax/Asia-Pacific-tax-policy-outlook.

Faridy, N., and T. Sarker (2011). Progressivity of value added tax (VAT) in developing countries: empirical evidence from Bangladesh. Asia Pacific Tax Bulletin, vol. 17, No. 3, pp. 185-191.

Food and Agriculture Organisation (2002). Rural property tax systems in Central and Eastern Europe. Available from www.fao.org/DOCREP/005/Y4313E/y4313e05.htm.

Fuest, C. (2009). The UK should increase VAT. The Tax Journal, pp. 24-25.

Gosseries, A. (2008). Theories of intergenerational justice: a synopsis. Surv. Perspect. Integr. Environ. Soc., vol. 1, pp. 39-49.

Haque, M. (2011). Property tax be imposed to finance education policy implementation. Holiday, 1 April.

Hassan, B., and T. Sarker (2012). Reformed general sales tax in Pakistan. International VAT Monitor, vol. 23, No. 6, pp. 417-421.

International Finance Corporation (2001). Education sector strategy. Available from www.ifc.org/ ifcext/che.nsf/Content/StrategyE.

International Institute for Educational Planning (2007). Higher education and development. Newsletter, vol. 25, No. 1.

International Monetary Fund (IMF) (2011a). World Economic Outlook Report: Tensions from the Two-speed Recovery. Washington, D.C. Available from www.imf.org/external/pubs/ft/ weo/2011/01/. 
(2011b). Revenue Mobilization in Developing Countries. Washington, D.C.

(2013a). Bangladesh: country report, No. 13/357 (December). Washington, D.C.

(2013b). Pakistan: country report, No. 13/287 (September). Washington, D.C.

(2013c). Sri Lanka: country report, No. 13/120 (December). Washington, D.C.

(2014a). India: country report, No. 14/57 (February). Washington, D.C.

(2014b). Nepal: country report, No. 14/214 (July). Washington, D.C.

Jha, R. (2010). Fiscal policies and challenges in South Asia. ASARC Working Paper, 2010/01. Canberra: Australian National University.

Kazi, W.B., and T. Sarker (2012). Fiscal sustainability and the natural resource curse in resource rich African countries: a case study of Uganda. Bulletin for International Taxation, vol. 66, No. 8, pp. 1-12.

Kenyon, D.A. (2007). The Property Tax-School Funding Dilemma. Cambridge: Lincoln Institute of Land Policy.

Kim, Seung-Rae. (2005). Optimal fiscal policies for sustainable development: greening the tax and budget system. Paper presented at the UNESCAP-KAPFEKIPF Symposium: First Regional Policy Dialogue.

Kotlikoff, L.J., and L.H. Summers (1987). Tax incidence. Working Paper, No. 8829. Cambridege, MA: National Bureau of Economic Research.

KPMG (2011). Economic analysis of the impacts of using GST to reform taxes. CPA Australia.

Kunzel, P., and others (2011). Investment objectives of sovereign wealth funds-a shifting paradigm. Working Paper, No. WP/11/19. Washington, D.C.: IMF.

Lewin, K., and F. Caillods (2001). Financing Secondary Education in Developing Countries: Strategies for Sustainable Growth. Paris: UNESCO, International Institute for Educational Planning.

Mikesell, R.F. (1989). Depletable resources, discounting and intergenerational equity. Resources Policy, vol. 15, No. 4, pp. 292-296.

Mirrlees, J. (2011). Professor Sir James Mirrlees on poverty and redistribution. Available from http://beta.adb.org/features/professor-sir-james-mirrlees-poverty-and-redistribution.

New Zealand Treasury (2013). Affording our future: statement on New Zealand's long term fiscal position. Available from www.treasury.govt.nz. Accessed 17 October 2014.

Norwegian Ministry of Finance (2007). Background note: Norway's position in relation to the international debate on Sovereign Wealth Funds. Available from www.regjeringen.no/ globalassets/upload/fin/statens-pensjonsfond/swf-memo-oct07-off.pdf.

Organisation for Economic Co-operation and Development (OECD) (2010). What are the economic benefits of education? Available from www.oecd-ilibrary.org/education/education-at-aglance-2010/what-are-the-economic-benefits-of-education_eag-2010-11-en.

Porritt, J. (2003). The World in Context: Beyond the Business Case for Sustainable Development. Available from www.cisl.cam.ac.uk/publications/the-world-in-context.

Pressman, S. (2002). Income guarantees and the equity-efficiency tradeoff. Discussion Paper, No. 21. U.S. Basic Income Guarantee Network. Available from www.usbig.net/papers/021Pressman.doc. 
Reiche, D. (2010). Sovereign wealth funds as a new instrument of climate protection policy? A case study of Norway as a pioneer of ethical guidelines for investment policy. Energy, vol. 35, No. 9, pp. 3569-3577.

Sarker, T. (2006). Who bears the burden of taxes in developing dountries? A case of income taxation in Bangladesh. Pakistan Economic and Social Review, vol. 44, No. 2, pp. 181-207.

(2011a). Effective tax policy reform through strategic stakeholder communication: lessons from Australia. Bulletin for International Taxation, Journal IBFD, vol. 65, No. 10, pp. 582-590.

(2011b). Time for a property tax: how it may work. The Financial Express, 11 March.

(2013). Taxing for the future: an intergenerational perspective. In The Asian Century, Sustainable Growth and Climate Change, Moazzem Hossain, Tapan Sarker and Malcolm Mclntosh, eds. Cheltenham, UK: Edward Elgar Publishing.

Sarker, T., and M. Azam (2014). Mainstreaming climate change adaptation through technology transfer in developing countries: a climate hotspot case from coastal Bangladesh. In Responding to Climate Change: Lessons from an Australian Hotspot, P. Burton, ed. Clayton, Victoria, Australia: CSIRO Publishing.

Scholl, G., and others (2010). Policies to promote sustainable consumption: innovative approaches in Europe. Paper presented at the Natural Resources Forum.

Shuhong, K., L. Zhenzi, and M. Peter van der Hoek (2008). The dual corporate income tax in China: the impact of unification. Public Finance \& Management, vol. 8, No. 4, pp. 656-677.

Sigma Project (2003). The Sigma guidelines - toolkit: SIGMA guide to the global reporting initiative sustainability reporting tool. London. Available from projectsigma.co.uk/Toolkit/ SIGMAGlobalReporting.pdf.

Slack, E., and R. Bird (2013). Does municipal amalgamation strengthen the financial viability of local government? A Canadian example. Public Finance \& Management, vol. 13, No. 2, pp. 99-123.

Smith, A. (1776). The Wealth of Nations (Modern Library Classics). Oxford: Oxford University Press.

Southalan, J. (2011). What are the implications of human rights for minerals taxation? Resources Policy, vol. 36, No. 3, pp. 214-226.

Sunley, E.M., T. Baunsgaard, and D. Simard (2003). Revenue from the oil and gas sector: issues and country experience. Fiscal Policy Formulation and Implementation in Oil-Producing Countries, pp. 153-183.

Tanzi, V., and H. Zee (2001). Tax policy for developing countries. Economic Issues, vol. 27. Washington, D.C.: IMF.

Thompson, J. (2003). Intergenerational equity: issues of principle in the allocation of social resources between this generation and the next. Australia: Department of the Parliamentary Library.

United Nations Development Programme (UNDP) (2013). Human Development Report 2013 Summary The Rise of the South: Human Progress in a Diverse World. New York. Available from http://hdr.undp.org/en/content/human-development-report-2013-summary.

Wang, W., X. Zheng, and Z. Zhao (2012). Fiscal reform and public education spending: a quasinatural experiment of fiscal decentralization in China. Publius: The Journal of Federalism, vol. 42 , No. 2, pp. 334-356. 
World Bank (2014a). Bangladesh at a glance. Available from http://devdata.worldbank.org/AAG/ bgd_aag.pdf.

(2014b). Global Economic Prospects: Shifting Priorities, Building for the Future. Washington, D.C.

(2015). Global Economic Prospects: Having Fiscal Space and Using it. Washington, D.C. 